\title{
PHYSICAL ACTIVITY AND MOTOR DEVELOPMENT OF CHILDREN: THE USE OF TGMD-2
}

\author{
Marcus Vinicius de Melo', Renato Feitosa do Nascimento', Vivian de Oliveira², Ivan Wallan Tertuliano'.
}

\begin{abstract}
Background: Motor development can be understood as constant and permanent changes in the capacity to generate motor responses, which occur throughout the life cycle and may vary, influenced by the environment, task and the subjects themselves. Objectives: The present study aimed to review studies in the literature that used the Test of Gross Motor Development - Second Edition (TGMD2) to investigate the influence of physical activity on the motor performance of children aged 6-10 years. Methods: For this purpose, it was searched references in electronic search engines and organized them in the form of a systematic review. Searches took place between May and October 2017. As inclusion criterion it was used studies with children aged 6-10 years old that used the TGMD-2 as a motor assessment instrument. In addition, studies that were not related to physical activity or to TGMD-2 were excluded and, finally, only studies published in the Portuguese language were reviewed. Results: Studies have shown that children have poor performance in locomotor skills and that physical activities taught by the Physical Education teacher are more effective in improving locomotor skills. Conclusion: Thus, it can be concluded that the TGMD-2 is an adequate instrument for evaluation of motor development and that, in addition, the role of Physical Education teacher is important in the motor improvement process.
\end{abstract}

Keywords: Sensory-motor development; Child; Physical Activity; Physical Education.

\section{INTRODUCTION}

From birth the human being comes into contact with the world through the movement of his body, and it is through this movement that he expresses physiological, cognitive and psychosocial needs, such as the instinct for survival, discomfort, joy, among many other manifestations ${ }^{(1)}$. Human development is constant and occurs throughout life. An example of this can be observed in the cells that make up the human body, which evolve from conception to death ${ }^{(2)}$. Thus, development can be understood as a process of evolution, in which the human being will always be in transformation.

According to Papalia and Feldman ${ }^{(1)}$, development is divided into three main domains: physical, cognitive and psychosocial. Examples of physical development include body and brain growth, sensory abilities, motor skills, and health. Whereas examples of cognitive development can be learning, attention, memory, language, thought, reasoning and creativity. Finally, examples of psychosocial development are emotions, personality and social relations, and although they are treated and studied separately, they are interrelated, one depends on the other to develop. Entering specifically the subject of the physical domain, the Motor Development, Gallahue et al. ${ }^{(3)}$ showed the importance of individuality in development, i.e., each one has their own time to acquire movement, undergoing influence of maturation, environment and heredity. However, current studies point to the task and experience as major influencers in the motor development process $^{(4)}$. Corroborating this, Soares et al. ${ }^{(5)}$ pointed to the importance of physical activity in childhood, even for children with complaints of learning difficulties, with the aim of contributing to motor development and motor repertoire acquisition. In addition, the authors point out that there is a need for people to understand this process, since they will give the first tasks to the child, having a great influence on the practice of physical activity in childhood. However, to understand Motor Development, appropriate analysis tools are needed. One of the instruments that the literature shows as effective for this purpose is the Test of Gross Motor Development $(\mathrm{TGMD})^{(6,7)}$. This instrument was proposed by Ulrich in 1985 and updated in 2000, being called TGMD- $2^{(8)}$. The TGMD-2 has adequate measures to evaluate the process of motor development of children aged 3-11 years, i.e., it is able to assess if children have delayed motor development, which can contribute to the adequate planning of motor intervention programs. In view of the above, the present study aims to

Corresponding Author: Ivan Wallan Tertuliano. Address: Estrada de Itapecerica, 5859, Capão Redondo, Cep 05858-001. Tel: +55 (11) 2128-6000. São Paulo/SP, Brazil. E-mail: ivanwallan@gmail.com

${ }^{1}$ Centro Universitário Adventista de São Paulo - UNASP - São Paulo (SP), Brazil.

Full list of author information is available at the end of the article.

Financial Support: None.

Submission date 25 May 2018; Acceptance date 05 July 2018; Publication date 23 October 2018 
review studies in the literature that used the Test of Gross Motor Development - Second Edition (TGMD-2) to investigate the influence of the practice of physical activity on the motor performance of children aged 6-10 years. The information from the present study is expected to provide a better understanding of the motor development process of children.

\section{METHODS:}

Between May and October 2017, was made a search of articles, theses and dissertations between 2007 and 2017 in Google Scholar and Scielo databases with the following descriptors: motor development, children, physical activity, exercise and child, middle childhood (age between 6 and 10 years), TGMD-2. Review articles were excluded, as were those who were newest or oldest than described before. Studies that were not related to physical activity nor to TGMD-2 were also excluded. Only studies published in the Portuguese language were reviewed. The search performed found 265 works, totaling the results of all bases used, being 210 in Google Scholar and 55 in Scielo. Of this total of 265, 241 are articles, 10 are theses and 14 are Master Degree dissertations. The 265 studies were selected for the title reading, 50 were considered possibly relevant and had their abstracts evaluated. Of these, 22 were excluded because they did not meet the inclusion criteria, and 28 were selected for full reading. Of this total, 15 were considered relevant for this study, being 13 articles, 1 thesis and 1 dissertation. Initially, it analyzed the titles and summaries of the works found, looking for references of the terms used to search and their relation with the objective of the study. After this phase, the appropriate papers were separated for use in the present study. After the inclusion and exclusion criteria mentioned above, the total number used to describe the results of the present study and which comprised the objectives of this study were 15 articles. Figure 1 shows the search process, inclusion and exclusion of articles, theses and dissertations present in the current literature.

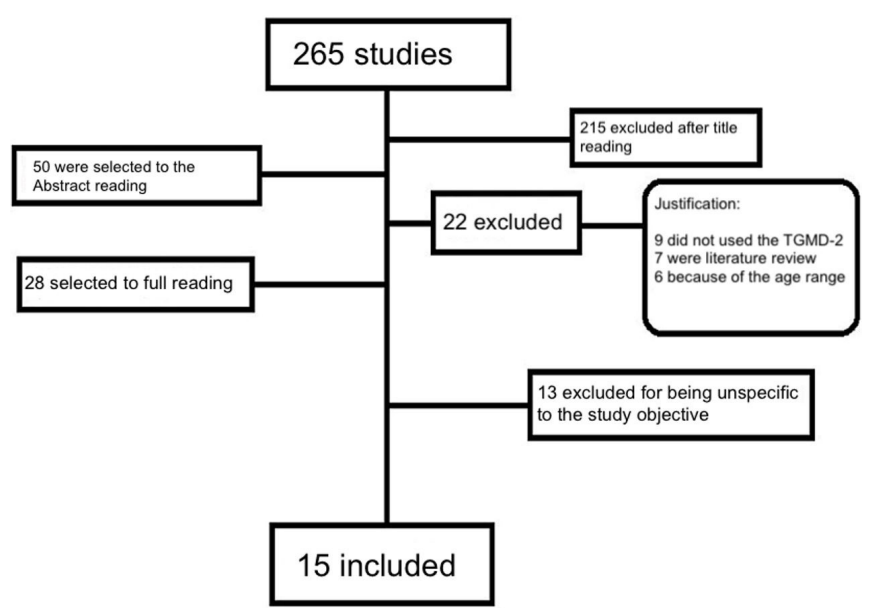

Figure 1: Selection process of the papers used in this study.

\section{RESULTS AND DISCUSSION}

\section{Motor Development}

Motor development can be understood as constant and permanent changes in the capacity to generate motor responses, which occur throughout the life cycle ${ }^{(3)}$ and may vary, influenced by the environment, task and the subjects themselves ${ }^{(4)}$. Thus, motor development is considered as a sequential, continuous process and related to the chronological age, by which the human being acquires an enormous amount of motor skills that progress from simple and disorganized movements to the execution of highly organized and complex motor skills ${ }^{(9)}$. Therefore, Willrich et al. ${ }^{(6)}$ points out that during the motor development the child must be observed with great attention to identify the stage in which it is, to diagnose possible delays in motor development that can compromise aspects of adult life. Then, it is important to know and identify the phases and stages of motor development, as well as their characteristics, so that appropriate interventions can be made, facilitating the adequate motor development process. According to Gallahue et al. ${ }^{(3)}$, motor development is divided into four phases: reflexive (stages of coding and decoding), rudimentary (stages of inhibition of reflexes and pre-control), fundamental (initial, elementary and mature stages) and specialized stages (transition, application and lifelong application stages). In addition, human development occurs in phases and is influenced by hereditary and contextual issues.

In contrast, Haywood e Getchel ${ }^{(4)}$, used a Newell model ${ }^{(10)}$ to explain the motor development. According to the Newell model, the movements arise from the interactions of the subject, the task and the environment, that is, one factor has direct influence on the other. Thus, it is understood that if one of the factors (subject, task and environment) changes, the movement must change and to these sum of changes gives the process of motor development. Such factors are called restrictions by Newell. Restrictions are as individual and environmental constraints that are in direct relation to the task (movement). The main restrictions described by Newell ${ }^{(10)}$ are: subject restrictions (unique physical and mental characteristics, divided into structural and functional constraints), environmental restrictions (constraints on the space that surrounds him/her), task restrictions (equipment, rules, goals, influencing him/her). In view of the above, it is observed that several factors can interfere in the "normal course" of motor development, such as family, friends, professors and the environment where they are inserted ${ }^{(4)}$.

In the case of motor development, there are some instruments that help the Physical Education teacher in the diagnosis of the motor development process. One of the existing instruments is the TGMD ${ }^{(11)}$, proposed in 1985 by Dale Ulrich, with the purpose of evaluating the quality of the movement related to the fundamental motor skills, being able to classify them in different motor levels. In 2000, Ulrich 
released a second version of the same test, the TGMD $2^{(8)}$. TGMD-2 is constituted by two subtests: locomotion and control of objects. Each subtest contains six fundamental motor skills assessed. The locomotor subtest evaluates running, galloping, jumping with one foot, jumping over an object, jumping horizontally and lateral displacement. Whereas the control of objects subtest evaluates the bouncing of a ball, bouncing it without displacement, receiving it, kicking it, throwing it over the shoulder and tossing it under the shoulder ${ }^{(8)}$.

All the above mentioned skills are assessed in isolation, using established criteria. When the evaluated meets the criteria, it is assigned a point, otherwise it is not assigned any points. The assigned points are summed and the total value of points obtained for each subtest reflects the pattern of the movement performed. These values can be considered, for example, as a gross score or, if it is of interest, the equivalent motor age can be defined from the gross score of each subtest. Taking as reference TGMD and TGMD-2, some studies were conducted ${ }^{(12,13)}$. In summary, based on the results and discussions of the cited studies, it is understood that TGMD-2 is suitable for studies that investigate motor development in children and, therefore, this instrument was assumed in the present study.

\section{The use of TGMD-2 for understanding motor development}

As previously mentioned, motor development can be understood with the aid of different instruments, among them TGMD-2, which is the focus of the present study. Thus, tables 1 and 2 present the papers used in this review, with a brief summary of their objectives, methodologies, results and conclusions, periodicals and databases.
Studying the motor development, focusing in TGMD, Catenassi et al. ${ }^{(14)}$ verified the relationship between performance in tasks of gross motor skill and BMI in boys and girls. For this, 27 children were analyzed: 11 girls and 16 boys, aged 4 to 6 years. The authors evaluated the motor performance with the use of TGMD-2 and evaluated the BMI with the use of anthropometric information. The results showed that no significant interactions of the evaluated variables were observed both in the comparison between genders and the BMI. In view of such results, the authors concluded that BMI is not related to performance in gross motor skills in children aged 4 to 6 years. Aiming to investigate the effects of a motor intervention program in obese and non-obese children on motor, nutritional and psychosocial parameters, Berleze ${ }^{(15)}$ performed a study with 78 obese and non-obese children in two groups 38 in intervention group (IG) and 40 in control group (CG); age range of 5 to 7 years. The program lasted 28 weeks, with two weekly classes of 90 minutes each. In this period the CG did not have any type of intervention, and their activities within the research were merely evaluative, for about 5 weeks. The results showed that the GI had significant changes in a larger scale on motor, nutritional and psychosocial performance compared to the CG. The author concluded that the execution of a motor intervention program methodologically based and effective, promotes significant gains in parameters of motor, nutritional and psychosocial performance.

Brauner and Valentini(16) investigated the motor performance of children (5 to 6 years), practitioners of physical activities related to the family and biological context. A questionnaire was developed specifically for the study

Table 1: Information about the studies.

\begin{tabular}{|c|c|c|c|c|}
\hline First Author & Year & Periodic & Age range & $\mathbf{N}$ \\
\hline Catenassi, F. Z. & 2007 & Revista Brasileira de Medicina do Esporte & 4 to 6 & 27 \\
\hline Berleze, A. & 2008 & PhD Thesis UFRGS & 5 to 7 & 78 \\
\hline Brauner, L. M. & 2009 & Revista da Educação Física/UEM & 5 to 6 & 32 \\
\hline Braga, R. K. & 2009 & Revista da Educação Física/UEM & 6 to 7 & 60 \\
\hline Palma, M. S. & 2009 & Revista da Educação Física/UEM & 5 to 6 & 71 \\
\hline Brauner, L. M. & 2010 & Master Degree Thesis UFRGS & 5 to 9 & 140 \\
\hline Cotrim, J. R. & 2011 & Revista da Educação Física/UEM & 9 to 11 & 30 \\
\hline Lopes, L. O. & 2011 & Revista Brasileira de Cineantropometria e Desempenho Humano & 6 to 7 & 21 \\
\hline Krebs, R. J. & 2011 & Revista Brasileira de Cineantropometria e Desempenho Humano & 7 to 8 & 50 \\
\hline Araújo, M. P. & 2012 & Revista Brasileira de Medicina do Esporte & 9 to 10 & 41 \\
\hline Nobre, F. S. S. & 2012 & Revista ACTA Brasileira do Movimento Humano & 4 to 6 & 46 \\
\hline Palma, M. S. & 2012 & Revista de Educação Física/UEM & 4 to 6 & 88 \\
\hline Rodrigues, D. & 2013 & Revista Motriz & 4 to 6 & 50 \\
\hline Fernandes, P. S. & 2014 & Revista Kinesis & 7 to 9 & 40 \\
\hline Fernandes, L. A. & 2017 & Revista Educação Especial & 10 & 8 \\
\hline
\end{tabular}


Table 2: Reviewed studies

\begin{tabular}{|c|c|c|c|c|c|}
\hline Author (Year) & Objective & Method & Result & Conclusion & Database \\
\hline $\begin{array}{l}\text { Catenassi et al. } \\
\text { (2007) }\end{array}$ & $\begin{array}{l}\text { - To verify the } \\
\text { relation between the } \\
\text { performance in tasks of } \\
\text { gross motor skill with } \\
\text { the body mass index } \\
\text { (BMI). }\end{array}$ & $\begin{array}{l}\text { - TGMD- } 2 \text { and KTK, and } \\
\text { Anthropometric use; } 27 \\
\text { children ( } 11 \text { girls and } 16 \\
\text { boys), with age between } 4 \\
\text { and } 6 \text { years. }\end{array}$ & $\begin{array}{l}\text { - No interaction between } \\
\text { performance, } \mathrm{BMI} \text { and age. }\end{array}$ & $\begin{array}{l}\text { - The IMC is not related } \\
\text { to performance in tasks } \\
\text { of gross motor skills in } \\
\text { children. }\end{array}$ & Scielo \\
\hline Berleze (2008) & $\begin{array}{l}\text { - To investigate the } \\
\text { effects of a motor } \\
\text { intervention program } \\
\text { in obese and non- } \\
\text { obese children on } \\
\text { motor, nutritional } \\
\text { and psychosocial } \\
\text { parameters. }\end{array}$ & $\begin{array}{l}\text { - TGMD-2, and } \\
\text { Anthropometric use; } \\
78 \text { children ( } 38 \text { in the } \\
\text { Intervention Group and } 40 \\
\text { in the Control Group) with } 5 \\
\text { and } 7 \text { years. }\end{array}$ & $\begin{array}{l}\text { - The IG had significate } \\
\text { significant changes in motor, } \\
\text { nutritional and psychosocial } \\
\text { performance compared to } \\
\text { the CG. }\end{array}$ & $\begin{array}{l}\text { - A methodologically } \\
\text { based and effective motor } \\
\text { intervention program } \\
\text { promotes significant gains } \\
\text { in motor, nutritional and } \\
\text { psychosocial performance. }\end{array}$ & Google Scholar \\
\hline $\begin{array}{l}\text { Brauner and } \\
\text { Valentini (2009) }\end{array}$ & $\begin{array}{l}\text { - To investigate the } \\
\text { motor performance of } \\
\text { children practitioners } \\
\text { of physical activities, } \\
\text { related to the family } \\
\text { and biological context. }\end{array}$ & $\begin{array}{l}\text { - TGMD-2 and } \\
\text { Questionnaire; } 32 \text { children, } \\
\text { aged between } 5 \text { and } 6 \text { years. }\end{array}$ & $\begin{array}{l}\text { - The motor performance } \\
\text { level is lower than } \\
\text { expected. The family factor } \\
\text { did not influence motor } \\
\text { performance only the } \\
\text { parents' professions had an } \\
\text { impact. }\end{array}$ & $\begin{array}{l}\text { - Alert teachers of } \\
\text { children's programs, } \\
\text { having importance to } \\
\text { the development of } \\
\text { fundamental skills, and } \\
\text { harmonic development of } \\
\text { the subject. }\end{array}$ & Google Scholar \\
\hline $\begin{array}{l}\text { Braga et al. } \\
\text { (2009) }\end{array}$ & $\begin{array}{l}\text { - To investigate the } \\
\text { influence of a motor } \\
\text { intervention program } \\
\text { on the performance of } \\
\text { children's locomotor } \\
\text { skills. }\end{array}$ & $\begin{array}{l}\text { - TGMD-2; } 60 \text { children aged } \\
\text { between } 5 \text { and } 6 \text { years were } \\
\text { randomly distributed. }\end{array}$ & $\begin{array}{l}\text { - Significant difference in } \\
\text { the performance of the } \\
\text { treatment groups when } \\
\text { compared to the control } \\
\text { group after the intervention. } \\
\text { Being classified as below } \\
\text { average in the performance } \\
\text { of locomotive skills. }\end{array}$ & $\begin{array}{l}\text { - The scores showed } \\
\text { that there seems to be } \\
\text { a tendency for Brazilian } \\
\text { children to enter the } \\
\text { school context with a } \\
\text { low performance of the } \\
\text { locomotor skills. }\end{array}$ & Google Scholar \\
\hline $\begin{array}{l}\text { Palma et al. } \\
\text { (2009) }\end{array}$ & $\begin{array}{l}\text { - Investigate the } \\
\text { influence of movement } \\
\text { programs on motor } \\
\text { development and } \\
\text { engagement of } \\
\text { preschool children. }\end{array}$ & $\begin{array}{l}\text { - TGMD-2; } 71 \text { children ( } 22 \\
\text { Guided Game Group, } 24 \\
\text { Free Play Group, } 25 \text { Control } \\
\text { Group) aged } 5 \text { to } 6 \text { years. }\end{array}$ & $\begin{array}{l}\text { - The intervention promoted } \\
\text { gains in motor performance } \\
\text { and increased engagement } \\
\text { only in the Guided Game } \\
\text { Group. }\end{array}$ & $\begin{array}{l}\text { - The development of motor } \\
\text { skills and engagement in } \\
\text { movement programs are } \\
\text { dependent on the quality } \\
\text { of the environmental } \\
\text { conditions. }\end{array}$ & Google Scholar \\
\hline Brauner (2010) & $\begin{array}{l}\text { - To investigate changes } \\
\text { in motor performance, } \\
\text { perception of } \\
\text { competence, and the } \\
\text { routine of children's } \\
\text { activity in social sports } \\
\text { project and to identify } \\
\text { possible differences } \\
\text { related to gender. }\end{array}$ & $\begin{array}{l}\text { - TGMD- } 2 \text { and } \\
\text { Questionnaire; } 140 \text { children } \\
\text { of both genders between } 5 \\
\text { and } 9 \text { years. }\end{array}$ & $\begin{array}{l}\text { - Initial motor development } \\
\text { below expected, in addition } \\
\text { to significant changes in } \\
\text { motor development level. }\end{array}$ & $\begin{array}{l}\text { - Participation in a sports } \\
\text { social project based on } \\
\text { methodological proposals } \\
\text { promoted positive changes } \\
\text { in motor and psychological } \\
\text { terms in the routine of } \\
\text { children's activities. }\end{array}$ & Google Scholar \\
\hline $\begin{array}{l}\text { Cotrim et al. } \\
\text { (2011) }\end{array}$ & $\begin{array}{l}\text { - To verify the } \\
\text { development of } \\
\text { fundamental motor } \\
\text { skills in children who } \\
\text { have undergone } \\
\text { elementary school } \\
\text { and in different school } \\
\text { contexts. }\end{array}$ & $\begin{array}{l}\text { - TGMD-2; } 30 \text { children (15 } \\
\text { private school (CEPar), and } \\
15 \text { public school (CEPub), } \\
\text { aged between } 9 \text { and } 11 \\
\text { years. }\end{array}$ & $\begin{array}{l}\text { - CEPar indicated equivalent } \\
\text { motor age inferior to } \\
\text { chronological age for the } \\
\text { CEPub group. Thus, there } \\
\text { was no difference between } \\
\text { equivalent motor age and } \\
\text { chronological age for the } \\
\text { CEPar group. }\end{array}$ & $\begin{array}{l}\text { - The school context } \\
\text { influences the motor } \\
\text { development of children. }\end{array}$ & Scielo \\
\hline $\begin{array}{l}\text { Lopes et al. } \\
\text { (2011) }\end{array}$ & $\begin{array}{l}\text { - To analyze the } \\
\text { relationship } \\
\text { between habitual } \\
\text { physical activity and } \\
\text { fundamental motor } \\
\text { ability, and motor } \\
\text { coordination in } \\
\text { children. }\end{array}$ & $\begin{array}{l}\text { - TGMD- } 2 \text { and KTK; } 21 \\
\text { children aged } 6 \text { and } 7 \text { years. }\end{array}$ & $\begin{array}{l}\text { - Most of the children } \\
\text { presented CM disorders and } \\
\text { coordinative insufficiencies, } \\
\text { no subjects had a good or } \\
\text { very good CM. }\end{array}$ & $\begin{array}{l}\text { - These children had } \\
\text { insufficient coordinative } \\
\text { development and poor } \\
\text { development of HMF. }\end{array}$ & Google Scholar \\
\hline
\end{tabular}


Table 2: Continued...

\begin{tabular}{|c|c|c|c|c|c|}
\hline Author (Year) & Objective & Method & Result & Conclusion & Database \\
\hline $\begin{array}{l}\text { Krebs et al. } \\
\text { (2011) }\end{array}$ & $\begin{array}{l}\text { - The objective of this } \\
\text { study was to investigate } \\
\text { the relationship } \\
\text { between motor } \\
\text { performance scores } \\
\text { and physical fitness of } \\
\text { children. }\end{array}$ & $\begin{array}{l}\text { - TGMD- } 2 \text { and AAHPERD; } \\
50 \text { children ( } 25 \text { boys and } 25 \\
\text { girls) aged between } 7 \text { and } \\
8 \text { years. }\end{array}$ & $\begin{array}{l}\text { - They showed statistical } \\
\text { significance and weak } \\
\text { correlations in some skills. }\end{array}$ & $\begin{array}{l}\text { - The equivalent use of } \\
\text { both tests may not be } \\
\text { appropriate, since each test } \\
\text { has its own peculiarities } \\
\text { regarding the evaluation } \\
\text { criteria. }\end{array}$ & Google Scholar \\
\hline $\begin{array}{l}\text { Araújo et al. } \\
\text { (2012) }\end{array}$ & $\begin{array}{l}\text { - To investigate } \\
\text { the contribution } \\
\text { of PE classes in } \\
\text { elementary school to } \\
\text { the development of } \\
\text { fundamental motor } \\
\text { skills of children, and if } \\
\text { the practice of extreme } \\
\text { sports would improve } \\
\text { motor development. }\end{array}$ & $\begin{array}{l}\text { - TGMD-2; } 41 \text { children ( } 22 \\
\text { experimental group and } \\
19 \text { control group) aged } \\
\text { between } 9 \text { to } 10 \text { years. }\end{array}$ & $\begin{array}{l}\text { - The EG showed motor age } \\
\text { higher than chronological } \\
\text { age in the locomotor } \\
\text { subtest. EG children had } \\
\text { raw scores in the locomotor } \\
\text { subtest and the two groups } \\
\text { presented similar gross } \\
\text { scores in the control subtest. }\end{array}$ & $\begin{array}{l}\text { - PE classes in elementary } \\
\text { school contributed to } \\
\text { the development of } \\
\text { fundamental motor skills. } \\
\text { Radical sports classes } \\
\text { further contributed to the } \\
\text { development of locomotor } \\
\text { skills. }\end{array}$ & Scielo \\
\hline $\begin{array}{l}\text { Nobre et al. } \\
(2012)\end{array}$ & $\begin{array}{l}\text { - To describe and } \\
\text { compare the motor } \\
\text { development of } \\
\text { children involved in } \\
\text { a motor intervention } \\
\text { program and children } \\
\text { who do not take } \\
\text { Physical Education } \\
\text { classes. }\end{array}$ & $\begin{array}{l}\text { - Teste TGMD- } 2 \text {; } 46 \text { children } \\
\text { ( } 23 \text { in the intervention group } \\
\text { and } 23 \text { in the control group) } \\
\text { aged between } 4 \text { and } 6 \text { years. }\end{array}$ & $\begin{array}{l}\text { - Better for the GI compared } \\
\text { to the CG. }\end{array}$ & $\begin{array}{l}\text { - Only the activities carried } \\
\text { out in the school are not } \\
\text { enough to stimulate a } \\
\text { good motor performance; } \\
\text { the activities in another } \\
\text { context as cultural issues are } \\
\text { activities of the daily games. }\end{array}$ & Google Scholar \\
\hline $\begin{array}{l}\text { Palma et al. } \\
(2012)\end{array}$ & $\begin{array}{l}\text { - To evaluate and } \\
\text { compare the motor } \\
\text { performance of } \\
\text { preschoolers practicing } \\
\text { and not practicing } \\
\text { systematic physical } \\
\text { activity. }\end{array}$ & $\begin{array}{l}\text { - TGMD-2 and } \\
\text { Questionnaire; } 88 \text { children } \\
\text { (52 practitioners and } 36 \\
\text { non-practitioners) aged } \\
\text { between } 4 \text { and } 6 \text { years. }\end{array}$ & $\begin{array}{l}\text { - Although both exhibited } \\
\text { motor performance lower } \\
\text { than expected, practitioners } \\
\text { presented better } \\
\text { performance in locomotor } \\
\text { skills, object control and the } \\
\text { motor coefficient. }\end{array}$ & $\begin{array}{l}\text { - Regular and systematized } \\
\text { physical activities need } \\
\text { to be part of a program } \\
\text { for childhood, because it } \\
\text { helps to achieve a broader } \\
\text { development of children's } \\
\text { abilities. }\end{array}$ & Google Scholar \\
\hline $\begin{array}{l}\text { Rodrigues et al. } \\
\text { (2013) }\end{array}$ & $\begin{array}{l}\text { - To verify the effects } \\
\text { of different contexts } \\
\text { in the development of } \\
\text { fundamental motor } \\
\text { skills and somatic } \\
\text { growth of children in } \\
\text { kindergarten. }\end{array}$ & $\begin{array}{l}\text { - TGMD- } 2 \text { and } \\
\text { Anthropometric use; } 50 \\
\text { children ( } 25 \text { had activities } \\
\text { with the classroom teacher } \\
\text { and } 25 \text { had Physical } \\
\text { Education classes with a } \\
\text { specialist of the area) aged } \\
\text { between } 4 \text { and } 6 \text { years. }\end{array}$ & $\begin{array}{l}\text { - Children who had activities } \\
\text { with the classroom teacher } \\
\text { had a reduction in the level } \\
\text { of physical activity, children } \\
\text { with classes with the } \\
\text { specialist teacher presented } \\
\text { maintenance at the level of } \\
\text { AF and better development } \\
\text { of motor skills. }\end{array}$ & $\begin{array}{l}\text { - The different contexts of } \\
\text { physical education classes } \\
\text { are not enough to promote } \\
\text { somatic change in children. } \\
\text { However, classes with the } \\
\text { specialist teacher better } \\
\text { develop the fundamental } \\
\text { motor skills. }\end{array}$ & Google Scholar \\
\hline $\begin{array}{l}\text { Fernandes and } \\
\text { Palma (2014) }\end{array}$ & $\begin{array}{l}\text { - To evaluate and } \\
\text { compare the level of } \\
\text { motor performance } \\
\text { of practicing and non- } \\
\text { practitioners of Physical } \\
\text { Education. }\end{array}$ & $\begin{array}{l}\text { - TGMD-2; } 40 \text { children ( } 20 \\
\text { practitioners and } 20 \text { non- } \\
\text { practitioners of physical } \\
\text { activity) aged between } 7 \\
\text { and } 9 \text { years. }\end{array}$ & $\begin{array}{l}\text { - No significant difference } \\
\text { was observed between the } \\
\text { two groups, both of which } \\
\text { contained a very poor motor } \\
\text { performance level. }\end{array}$ & $\begin{array}{l}\text { - There were limitations } \\
\text { in the study: the lack of } \\
\text { quality control of the School } \\
\text { Physical Education program } \\
\text { and the reduced sample } \\
\text { size. }\end{array}$ & Google Scholar \\
\hline $\begin{array}{l}\text { Fernandes et al. } \\
\text { (2017) }\end{array}$ & $\begin{array}{l}\text { - To analyze the motor } \\
\text { development of } \\
\text { children with Attention } \\
\text { Deficit Hyperactivity } \\
\text { Disorder. }\end{array}$ & $\begin{array}{l}\text { - TGMD-2; } 8 \text { male children } \\
\text { with mean age of } 10 \text { years. }\end{array}$ & $\begin{array}{l}\text { - They demonstrated that } \\
\text { children with ADHD had } \\
\text { a marked motor deficit in } \\
\text { object control skills. }\end{array}$ & $\begin{array}{l}\text { - There is a need for regular } \\
\text { and systematic physical } \\
\text { activity programs; children } \\
\text { with ADHD present a delay } \\
\text { in motor performance. }\end{array}$ & Google Scholar \\
\hline
\end{tabular}

and motor performance was assessed through the TGMD-2. The sample contained 32 children of both genders. A lower motor performance level was observed for the age range. The fact of having siblings and regular practice of physical activity of the parents does not seem to influence the motor performance. It has also been shown that parental occupations had an impact on the participants' performance. The authors concluded that it is necessary to warn teachers and coordinators of children's programs about the importance of the development of fundamental skills, so that there can 
be a balance between the practices carried out, with a view to a harmonious development of the subject.

In order to investigate the influence of a motor intervention program on the performance of the locomotor skills of children aged 6 to 7 years, Braga et al. ${ }^{(17)}$ studied a sample of 60 students who were randomly distributed, in a paired manner, in three groups: (G1) random practice group, (G2) practice in phases group and (G3) control group. All groups were assessed pre and post intervention through the TGMD-2. The results showed a significant difference in the means of performance of the treatment groups, when compared to the control group, after the intervention. The study participants were identified and classified as below the expected performance average of locomotor skills. The authors conclude that there seems to be a tendency for Brazilian children to enter the school context, with a low performance of locomotor skills.

In order to investigate the influence of different motion programs on motor development and the engagement of preschoolers, Palma et al. ${ }^{(18)}$ performed a research in which had a sample of 71 children ( 5 and 6 years). The participants were divided into 3 experimental groups: Guided Game Group ( $n=22)$, Free Play Group $(n=24)$ and a Control Group $(n=25)$. The experimental groups participated in different programs: game with guidance and a free game in a enriched context. TGMD-2 was applied for motor development analysis. The results demonstrated that the intervention promoted gains in motor performance only in the Guided Game Group. During the interventions, the Guided Game Group showed greater engagement, compared to the other groups. Thus, the authors concluded that the development of motor skills and engagement of children in movement programs are dependent on the quality of environmental conditions.

In order to investigate the changes in the motor performance, the perception of competence, and the routine of children's activity of the participants of a sports social project and to identify possible differences related to gender, Brauner ${ }^{(19)}$ recruited 140 children of both sexes between the ages of 5 and 9 years, and distributed them into two groups: intervention group (IG) and control group (CG). The instruments used were: TGMD-2 and Neto and Serrano Questionnaire ${ }^{(20)}$. The results showed lower initial motor development than expected, as well as significant changes in the motor development level of GI participants and better performance compared to participants of CG. No changes were observed in relation to gender in the $\mathrm{Gl}$, but an indication of advantage was found for males in CG. In view of the results, the author concluded that participation in a sports social project based on efficient and specific methodological proposals with the participants' needs promoted positive changes in motor and psychological terms and in the routine of children's activities.

Cotrim et al. ${ }^{(21)}$ verified the development of fundamental motor skills in children who attended elementary school in different school contexts. Fifteen children from a public school (CEPub) and fifteen children from a private school (CEPar) were randomly selected, and both enrolled in the 5 th year of Elementary School. All children were evaluated by performing the subtests: Locomotor and Object Control of TGMD-2. The results demonstrate motor age below the chronological age for the CEPub group in the Object Control subtests. However, a difference between equivalent motor age and chronological age was not observed for the CEPar group. The authors concluded that the school context influences the motor development of children.

Aiming to analyze the relationship between usual physical activity, fundamental motor ability (HMF) and motor coordination (MC) in children, Lopes et al. ${ }^{(22)}$ conducted a study with 21 children of both sexes, aged 6 to 7 years. The usual physical activity was evaluated by accelerometer, the fundamental motor skills were analyzed using the TGMD-2 and the motor coordination was evaluated through the Körperkoordination Test für Kinder (KTK). The results showed that no subject presented a good or very good MC in KTK. Regarding the results of TGMD- 2 to locomotor evaluation, $76.2 \%$ were above the 50th percentile, $28.6 \%$ achieved the P50 or higher in objects control and $38.1 \%$ achieved the P50 or higher in the total score of the test. Through these results the authors concluded that these children presented low results, indicators of possible insufficiencies of the coordinated development and poor development of HMF. These findings demonstrate the need for a special intervention, namely in the area of Physical Education.

Krebs et al. ${ }^{(23)}$ conducted a study to investigate the relationship between motor performance and physical fitness in children. The sample contained 50 children, divided into 25 boys and 25 girls, aged between 7 and 8 years. The TGMD- 2 was used to assess motor performance. For the evaluation of physical fitness, were used 3 specific tests proposed by American Alliance of Health, Physical Education and Recreation (AAHPERD). The results demonstrated statistical significance and weak correlations in some skills such as passing, low pitch, running, jumping, horizontal jumping and medicine ball pitch. The authors concluded that the equivalent use of both tests may not be adequate, since each test has its own peculiarities regarding the evaluation criteria.

Araújo et al. ${ }^{(24)}$ investigated the contribution of Physical Education (PE) classes in elementary school to the development of fundamental motor skills of children, and the influence of extreme sports, in addition to PE classes, in motor development. The sample was composed of 41 children ( $9.6 \pm 0.5$ years), 22 were in the experimental group (EG) with 2 PE classes and 3 extreme sports classes weekly, and 19 ( $9.5 \pm 0.3$ years) were in the control group (CG) with 2 PE classes weekly. All children were filmed performing the motor skills of the locomotor and objects control subtests of the TGMD-2. The results showed that the EG presented higher motor age than the chronological 
age in the locomotor subtest, while CG children showed no difference between the two ages. The authors conclude that PE classes in the first four years of elementary school have contributed to the development of fundamental motor skills and that the development of locomotor skills is optimized when regular lessons and extracurricular classes are added, such as extreme sports classes.

Nobre et al. ${ }^{(7)}$ investigated the influence of a motor intervention program on children from 4 to 6 years of age. For this, the authors recruited 46 children divided in 2 experimental groups: intervention group (IG) and control group (CG), containing 23 participants each. Motor performance evaluation was performed using the tests of TGMD-2. The results found were better for the IG in relation to CG. In the male equivalent motor age there was an inferiority of CG over the IG, both had values of $5.06 \pm 1.56$ and $5.61 \pm 1.05$, respectively. In the female gender the GI presented a higher result than the $C G(5.83+0.59$ and $4.29+0$, respectively). As for the objects control equivalent age, CG also had lower values than IG with $4.53+0.80$ and $5.67+0.91$, respectively. In view of the findings, the authors concluded that the activities performed outside the school context, in isolation, are not beneficial for the motor development, as well as the activities carried out within the school environment. Thus, the authors suggest that the activities carried out together, i.e., when adding the activities inside and outside the school environment, produce better motor gains.

Palma et al. ${ }^{(25)}$ evaluated and compared the motor performance of pre-schoolers practicing and not practicing systematic physical activity. The sample consisted of 88 children (52 practitioners and 36 non-practitioners), aged between 4 and 6 years. TGMD- 2 was used to analyze the motor performance and a questionnaire was applied to verify the level of physical activity of the children. In view of the results, it was observed that, although both groups showed a motor performance below the expectation for their age, the practitioners performed better than non-practitioners in locomotor skills, object control and in the broad motor coefficient. The authors concluded that regular and systematized physical activities need to be part of a program for childhood as they contribute to the broader development of motor skills.

Rodrigues et al. ${ }^{(26)}$ verified the effects of different contexts in the development of the fundamental motor skills and in the somatic growth of children in kindergarten. The authors recruited 50 children aged 4 to 6 years: 25 children had activities with the classroom teacher and 25 had physical education classes with a specialist teacher. The children were evaluated at the beginning and end of the school year, and for the motor performance were performed the TGMD-2 subtests and the anthropometric assessments. At the beginning of the school year, no difference was observed between groups. At the end of the school year, children who had activities with the classroom teacher presented a reduction in the level of physical activity, while children who had PE classes with the specialist teacher showed maintenance in the level of physical activity and better development of motor skills. Therefore, the authors concluded that the different contexts of physical education classes are not sufficient to promote somatic change in children throughout the school year. However, Physical Education classes with the specialist teacher promote the development of fundamental motor skills and develop the maintenance of the level of physical activity in children in kindergarten, compared to the non-specialist teacher.

Fernandes and Palma ${ }^{(2)}$ evaluated and compared the level of motor performance of practitioners and non-practitioners of Physical Education. The sample consisted of 40 children aged between 7 to 9 years ( 20 practitioners e 20 non-practitioners). The instrument used for motor performance analysis was the TGMD-2. The results demonstrate that there was no significant difference between two groups, both of which contained a very poor level of motor performance. Therefore, the authors concluded that the non-difference may be involved with the lack of quality control of the Physical Education Program or the reduced sample size. Fernandes et al. ${ }^{(27)}$ analyzed the motor development of children with Attention Deficit Hyperactivity Disorder (ADHD) from the evaluation of the fundamental motor skills. The sample consisted of 8 male children with a mean age of 10.25 years. The motor skills test was performed through the TGMD-2. The results demonstrate that children with ADHD had a marked motor deficit in the control abilities of objects. The authors conclude that the results show the need for regular and systematic physical activity programs and allow us to conclude that children diagnosed with ADHD present a delay in motor performance when compared to children who are in agreement with what is expected for the age range.

\section{DISCUSSION}

The present study aimed to review the studies in the literature that used the TGMD-2 to investigate the influence of physical activity on the motor performance of children between 6 and 10 years of age, and with that, organize the content related to the theme. In view of this, the results are discussed below. Palma et al. ${ }^{(18)}$ found superiority in the variables of motor performance, motor skills and objects control by the children related to the guided game group when compared to the free play group. These findings corroborate the prepositions of Gallahue et al. ${ }^{(3)}$, that even if the practice of deliberate activities plays an important role in children's motor development, an environment that has quality intervention is necessary to reach the maximum potential of this development. This environment becomes increasingly important as children have been subjected to social and cultural changes that result in their engagement with physical activities, the pleasure of moving ${ }^{(7,18)}$ and, thereby reducing motor practices. According to Gallahue and Donnely ${ }^{(28)}$, the longer the period and the 
quality of practices presented to the child, the greater the likelihood of the individual developing their motor skills with high competence, ie, the lack of practice impairs the motor development process. These findings demonstrate the need for a qualified professional to intervene with children in the first school years, corroborating the study of Silveira ${ }^{(29)}$, in which the author points to the role of movement and sport as tools for acquiring motor skills, but since they are led by a Physical Education teacher.

In the study of Braga et al. ${ }^{(17)}$ was possible to verify the results of the social and cultural changes, since the results showed that there seems to be a tendency of the Brazilian children to enter the school context with a poor performance of locomotor skills. In addition to the study cited above, low motor skills scores were also observed in the samples from other studies included in this review ${ }^{(2,16,19,22,25,27)}$, demonstrating the need for an adequate school curriculum in the early years. According to Silveira ${ }^{(29)}$ the school curriculum that aims at the acquisition of motor skills must present different contents, which allow a wide acquisition of knowledge. However, an improvement on locomotive skills performance was observed in the groups after the intervention by a specialist teacher ${ }^{(5,15,17,19,25-27)}$. Among the reviewed studies that exposed comparisons between motor activities with and without teacher intervention only in the study of Fernandes and Palma ${ }^{(2)}$ there was no significant difference in the performance of the children, but the authors emphasize the limitations of the study as the lack of quality control in the program of the discipline and the reduced size of the sample.

There is a wide range of contents that contribute to the development of locomotor skills in children, but it is of great importance that they are planned and systematized ${ }^{(5,25)}$. However, as literature points out ${ }^{(7,16,18)}$, other influences are important for motor development, such as the environmental conditions in which the child lives, plays and is exposed naturally. Physical activities in social sports projects, children's programs and school context are important for the child's motor learning, in which activities are planned and oriented, seeking pleasure and playfulness, involving the child for a pleasurable learning and with gain of motor development ${ }^{(16,19,21)}$. Physical Education classes combined with activities outside the school environment prove to be efficient to increase gains in motor performance, as demonstrated by Araújo et al. ${ }^{(24)}$ when they investigated the practice of extreme sports in parallel with the school classes.

The school is often the place where the first contact with sports or physical activity occurs. Thus, Rodrigues et al. (26) emphasized the importance of variations of teaching in the school context, so that one can have pleasurable and motivating classes, with the purpose of obtaining better motor gains and adherence to the motor practice and, with that, to ensure that the child maintains constancy in physical activities or sports. In order to properly occur the motor development, stimulation is necessary, however, modern life habits tend to cause changes in motor experiences, drastically reducing children's motor experiments and altering, in a negative way, their motor development. Such changes in modern life lead children, increasingly early, into gadgets and electronic games, depriving them of activities and games involving motor actions such as fundamental motor skills ${ }^{(26)}$. Therefore, when children are not adequately stimulated, they may not achieve fundamental movement patterns for possible insertion into sports, games, and physical activities ${ }^{(1)}$. So when the supply of fundamental motor skills and practices is reduced, impairment may occur in the course of the child's motor development, causing an insurmountable barrier, recognized in the literature as a barrier of proficiency ${ }^{(3)}$. It highlights the role of the teacher, a fundamental professional to ensure an adequate motor development. However, this professional, for a more assertive service, must present some fundamental skills and abilities, which are obtained through an adequate formation ${ }^{(29)}$. In addition, the teacher should have the ability to organize, plan and intervene in order to lead the child to gains in motor skills and thereby improve the student's motor conditions. Such actions, due to the academic education, reflects to the school teacher, especially to the PE teacher, demonstrating the relevant role of the school in this process.

Based on the observations of Willrich et al. ${ }^{(6)}$, some studies were conducted aiming to understanding the role of motor intervention in the motor development of children. Araújo et al. (24) observed that PE classes taught by a qualified professional in the first four years of elementary school are of paramount importance for the development of the fundamental motor skills of childhood. In addition, the study above noted that if the sport is treated at that stage, motor development is optimized. Santos et al. ${ }^{(30)}$ observed that physical activities during childhood can lead to changes in various aspects of children's development, as well as a significant improvement in overall motor and balance indicators. In this context, systematized sports practices, in general, contribute significantly to the expansion of children's motor development. These findings corroborate the prepositions of Silveira ${ }^{(29)}$, in which the author points out the fundamental role of the school, in this case the appropriate curriculum and with coherent contents for the motor acquisition process. In view of the above, it is observed that children should be encouraged to practice physical activities and sports. However, such a practice must take place in a planned and organized way so that it contributes adequately to children's motor development ${ }^{(19)}$.

Therefore, in the early childhood the literature recommends the use of games and activities for the motor experimentation of the children ${ }^{(1)}$. From the second childhood it must be worked playful games, in which it is seek the socialization to the environment where they are inserted. In these activities, 
other children should be involved, which will help in the management of egocentrism, since the child will have to divide tasks and objects with other children. Finally, in the third childhood, motor development should be stimulated with more specific activities, involving more complex instructions, athletic skills and physical strength ${ }^{(4)}$.

Considering the above, it can be observed that physical activity promotes gains in motor performance in children from 6 to 10 years old. In addition, the results demonstrate that gains in motor development are more effective when the activities are given by PE professionals. These findings demonstrate the relevance of the PE teacher, since it is in the school that the child is inserted, being able to have contact with the practice of physical activity regularly during the PE classes. Added to this, the studies demonstrated that the age range between 6 and 10 years presents a sensitive period for the gain of motor skills, justifying again the role of the $P E$ teacher in the process of gains in motor performance. In this way, organizing intervention strategies and discussing public policies for the maintenance of PE School classes with a PE professional becomes necessary. However, these were not the objectives of the present study, demonstrating the need for new studies.

\section{CONCLUSION}

Despite the results pointed out, the present study presents the limitation of being a review study and, in addition, a review of studies published only in Portuguese. Thus, the generalization of the results becomes limited. Finally, it is expected that future research will be conducted, as it was not intended to end the discussion about the subject and, as already mentioned, studies that present the discussion about the insertion of the PE teacher in the motor activities is necessary, as well as studies comparing the results of different regions and cultures.

\section{AUTHORS CONTRIBUTIONS:}

IWT: study design; MVM and RFN: data collection; IWT and VO: critical review of the article. All authors read and approved the final manuscript.

\section{CONFLICTS OF INTEREST}

There were no conflict of interests or financial support.

\section{AUTHORS DETAILS}

${ }^{2}$ Centro Universitário FIEO - UNIFIEO - Osasco (RJ), Brazil.

\section{REFERENCES}

1. Papalia DE, Feldman RD. Desenvolvimento Humano. 12th ed. Porto Alegre: AMGH; 2013.

2. Fernandes PS, Palma MS. Nivel de desempenho motor de escolares praticantes e não praticantes de Educação Física. Kinesis. 2014;1(32):2440.

3. Gallahue DL, Ozmun JC, Goodway JD. Compreendendo o Desenvolvimento Motor. 7th ed. Porto Alegre: AMGH; 2013.
4. Haywood KM, Getchell N. Desenvolvimento motor ao longo da vida. 6th ed. Porto Alegre: ArtMed; 2016.

5. Soares DB, Porto E, Marco A, Azoni CAS, Capelatto I V. Influência da Atividade Física no Desempenho Motor de Crianças com Queixas de Dificuldades de Aprendizagem. Rev CEFAC. 2015;17(4):1132-42.

6. Willrich A, Azevedo CCF, Fernandes JO. Desenvolvimento motor na infância: Influência dos fatores de risco e programas de intervencão. Rev Neurociências. 2009;17(1):51-6.

7. Nobre FSS, Lima MSC, Bandeira PFR, Nobre GC. Intervenção motora como fator determinante no desenvolvimento motor: estudo comparativo e quase experimental. Rev Acta Bras do Mov Hum. 2012;2(2):76-85.

8. Ulrich D. Test of gross motor development-2. Austin: Prod-Ed; 2000.

9. Haywood KM, Getchell N. Desenvolvimento motor ao longo da vida. 5th ed. Porto Alegre: ArtMed; 2010.

10. Newell KM. Constraints on the development of coordination. In: WADE, G.; WHITING HTA, editor. Motor development in children: aspects of coordination and control. Dordrecht: Martinus Nijhoff; 1986. p. p.85-122.

11. Ulrich D. Test of gross motor development. Austin: Prod-Ed; 1985.

12. Sampaio DF, Valentini NC. Iniciação esportiva em ginástica rítmica: Abordagens tradicional e o clima motivacional para a maestria. Rev da Educ Fis. 2015;26(1):1-10.

13. Lemos AG. Physical Education in Kindergarten Promotes Fundamental Motor Skill Development. Adv Phys Educ. 2012;02(01):17-21.

14. Catenassi FZ, Marques I, Bastos CB, Basso L, Ronque ERV, Gerage AM. Relação entre índice de massa corporal e habilidade motora grossa em crianças de quatro a seis anos. Rev Bras Med do Esporte. 2007;13(4):227-30.

15. Berleze A. Efeitos de um programa de intervenção motora em crianças, obesas e não obesas, nos parâmetros motores, nutricionais e psicossociais. [Tese de Doutorado]. Porto Alegre: Universidade Federal do Rio Grande do Sul; 2008.

16. Brauner LM, Valentini NC. Análise do desempenho motor de crianças participantes de um programa de atividades físicas. Rev da Educ Física/ UEM. 2009;20(2):205-16.

17. Braga RK, Krebs RJ, Valentini NC, Tkac CM. A influência de um programa de intervenção motora no desempenho das habilidades locomotoras de crianças com idade entre 6 e 7 anos. Rev da Educ Física/UEM. 2009;20(2):171-81.

18. Palma MS, Pereira B, Valentini NC. Jogo com orientação: uma proposta metodológica para a educação física pré-escolar. Rev da Educ Física/UEM. 2009;20(4):529-41.

19. Brauner LM. Projeto Social Esportivo: impacto no desempenho motor, na percepção de competência e na rotina de atividades infantis dos participantes. [Dissertação de Mestrado]. Porto Alegre: Universidade Federal do Rio Grande do Sul; 2010.

20. Neto C, Serrano J. Jogo e desenvolvimento da criança. Lisboa: Ed. FMH; 1997.

21. Cotrim JR, Lemos AG, Néri Júnior JE, Barela JA. Desenvolvimento de habilidades motoras fundamentais em crianças com diferentes contextos escolares. Rev da Educ Física/UEM. 2011;22(4):523-33.

22. Lopes LO, Lopes VP, Santos R, Pereira BO. Associações entre actividade física, habilidades e coordenação motora em crianças portuguesas. Rev Bras Cineantropometria e Desempenho Hum. 2011;13(1):15-21.

23. Krebs RJ, Duarte MG, Nobre GC, Nazario PF, Santos JOL. Relação entre escores de desempenho motor e aptidão física em crianças com idades entre 07 e 08 anos. Rev Bras Cineantropometria e Desempenho Hum. 2011;13(2):94-9.

24. Araújo MP de, Barela JA, Celestino ML, Barela AMF. Contribuição de diferentes conteúdos das aulas de educação física no ensino fundamental I para o desenvolvimento das habilidades motoras fundamentais. Rev Bras Med do Esporte. 2012;18(3):153-7. 
25. Palma MS, Camargo VA, Pontes MFP, De Camargo VA, Pontes MFP. Efeitos da atividade física sistemática sobre o desempenho motor de crianças pré-escolares. Rev da Educ Física/UEM. 2012;23(3):421-9.

26. Rodrigues D, Avigo EL, Leite MMV, Bussolin RA, Barela JA. Desenvolvimento motor e crescimento somático de crianças com diferentes contextos no ensino infantil. Motriz. 2013;19(3 SUPPL):49-56.

27. Fernandes LA, Miranda DM, Ribeiro-Silva PC, Salvador MG, Lage GM. Uma análise do desenvolvimento motor de crianças com transtorno do déficit de atenção e hiperatividade (TDAH). Rev Educ Espec. 2017;30(57):115-28.
28. Gallahue DL, Donnelly FC. Educação física desenvolvimentista para todas as crianças. São Paulo: Phorte; 2008.

29. Silveira SR. Esporte Escolar: perspectivas de produção do Esporte da Escola. In: Machado AA, Tertuliano IW, editors. Educação Física e Esportes: novos caminhos. São Paulo: Alexa Cultural; 2017. p. 13-30.

30. Santos CR, Silva CC, Damasceno ML, Medina-Papst J, Marques I. Efeito da atividade esportiva sistematizada sobre o desenvolvimento motor de crianças de sete a 10 anos. Rev Bras Educ Física e Esporte. 2015;29(3):497506. 